\title{
HBA1 wt Allele
}

National Cancer Institute

\section{Source}

National Cancer Institute. HBA1 wt Allele. NCI Thesaurus. Code C75431.

Human HBA1 wild-type allele is located in the vicinity of $16 \mathrm{p} 13.3$ and is approximately $1 \mathrm{~kb}$ in length. This allele, which encodes hemoglobin subunit alpha protein, plays a role in the regulation of vascular oxygen transport. Mutation or deletion of the gene is associated with alpha-thalassemia. 